\title{
A case study on the perceptions of forest owners on restoring the forests after a wildfire in the Treuenbrietzen forest of Branden- burg, Germany
}

\author{
Regine Frank ${ }^{1}$, Katrin Fröhlich ${ }^{1}$ and Somidh Saha ${ }^{1, *}$ \\ 1 Research Group Sylvanus, Institute for Technology Assessment and Systems Analysis, Karlsruhe Institute \\ of Technology, Karlstr. 11, 76133 Karlsruhe, Germany \\ * Correspondence: $\underline{\text { somidh.saha@kit.edu }}$
}

\begin{abstract}
Due to climate change, droughts have been occurring more frequently in Germany in recent years. More frequent and prolonged drought affects the health of trees and increases the risk of forest fires. A large-scale forest fire broke out near Treuenbrietzen, Brandenburg, in the summer of 2018 in pine monospecific forests. In addition to evaluating the damage caused, future reforestation is discussed, which is related mainly to the expectations of the forest owners. A telephone survey of seven affected forest owners was conducted using a semi-structured guided interview. The results from our interview demonstrated the support of private forest owners for mixed forests over monospecific pine forests. Most forest owners do not prioritize economic benefit with the forest land as forestry was not the primary source of income. Instead, the ownership of the forest tends to be linked to idealistic, cultural, and family values. The motives for reforestation vary but are often externally influenced. Different goals of forest owners lead to the challenge of finding consensus among them. We conclude that forestry advice by the federal and state governments is essential, especially on how climate change can affect local forests, to sensitize private forest owners to this problem.
\end{abstract}

Keywords: wildfire; private forest; reforestation; southeast Germany; qualitative study; pine monoculture; mixed forest

\section{Introduction}

Due to climate change, drought periods and dryness have become more frequent in Germany in recent years. Drought stress reduces the resistance of trees, giving pests easier access to weaken the trees further. Long-term drought affects the health of trees and forests and increases the risk of forest fires (MLUK 2019, BMEL 2020). In 2018 and 2019, the potential for forest fires increased at an above-average rate across Germany, with regional differences in the occurrence of forest fires. Among others, northeastern Germany is more frequently affected by forest fires (Glade et al. 2017; BLE 2020). Brandenburg, in particular, records the most fires, as well as the largest burned areas, due to sandy soils and widespread pine forests (Holsten et al. 2012; UBA 2020).

The background of this study is the outbreak of a large-scale forest fire in the Treuenbrietzen region near Brandenburg at the end of August 2018 (City of Treuenbrietzen, n.y.). The fire originated at several ignition points and was intensified by World War II ammunition and wind storm without rain. In total, an area of approximately 334 ha was damaged (MLUK 2018a). The site's vegetation consisted mainly of pine trees, which have almost wholly burned down (MLUK 2018b).

Numerous studies discuss silvicultural measures to increase the resilience of forests to disturbances such as drought and wildfire (Brang et al. 2014; Granados et al. 2016; Allgaier Leuch et al. 2017). 
How to implement this forest conversion concretely in the region of Treuenbrietzen is the basis of this study. Reforestation is of great importance and since the approximately 100,000 private forest owners own the majority of Brandenburg's forests, they play a major role in this (MLUL 2015).

Due to the high forest damage situation throughout Germany and the oversupply of wood, wood prices have developed strongly negatively. However, at the same time, the costs for planting material have increased. Against this background, the situation is challenging for many forest owners (Bathke \& Orlowski 2020). In this paper, we aim to answer two questions through interviewing forest owners:

(Q1) Do economic benefits play a significant role in the reforestation of burned areas?

(Q2) Do forest owners want to change their forest management in the future?

\section{Materials and Methods}

In the first step, a preliminary survey was conducted to obtain knowledge about the local situation and clarify the ownership of the land. Telephone calls were made to the district forester's office, Treuenbrietzen, the head forester's office, Dippmannsdorf and the chairman of the forest cooperative Bardenitz eG. Through the three institutions mentioned, contact was then established with the people whose areas were affected by the forest fire in 2018.

In the second step, qualitative guided interviews were conducted by telephone (Nieber \& Großengießer, 2014). Open-ended questions and a partially structured guide (Reinders, 2016) were used to narrow down topics and preformulate questions while at the same time leaving room for individual follow-up questions to allow openness to additions by the interviewees. The order of questions was also adapted to the course of the interview. Interview participants were selected using deductive sampling. Due to the prior knowledge from the preliminary survey, knowledge was available about which persons could provide information on the questions.

In the third step, the analysis took place. The interviews were transcribed using MAXQDA (after Kuckartz, 2018). A priori categories were formed as well as supplementary categories on the material during the data analysis (Kuckartz, 2018).

\section{Results}

\subsection{Sample Structure and Information}

A special feature of the sample composition was characterized by different ownership of the damaged area. In addition to private forest owners, the forest cooperative "Bardenitz eG" and the city of Treuenbrietzen also own forest land in the affected area. An attempt was made to conduct interviews with all three stakeholders in order to address different goals and intentions. A total of seven interviews were conducted, including four interviews with private forest owners and three interviews with members of the forest cooperative Bardenitz eG. Due to structural changes within the city administration, no interview could be conducted with the forest administration of the city of Treuenbrietzen at the time of the survey. There is a difference in ownership and management between the private forest owners and the Bardenitz forest cooperative, as the members of the forest cooperative have leased their forest areas to the cooperative and do not manage the areas themselves. This can create a discrepancy in knowledge about how to proceed and manage the land.

The majority of the seven respondents were male. None of the respondents had forestry qualifications, but five of the seven respondents had an agricultural connection, i.e., worked in agricultural areas or had contact with agriculture through family influence. Four of the respondents managed the forest area themselves, while three respondents had leased their areas to the forest cooperative and handed over management. Most of the respondents had come into possession of the forest through inheritance (see table 1). 
Table 1. The respondents profile $(n=7)$

\begin{tabular}{llrr}
\hline Attribute & Characteristic & Absolute & Percentage \\
\hline Gender & male & 5 & $71 \%$ \\
& female & 2 & $29 \%$ \\
\hline \multirow{2}{*}{ Education } & agricultural background & 5 & $71 \%$ \\
& other & 2 & $29 \%$ \\
\hline Management & private & 4 & $57 \%$ \\
& forest cooperative & 3 & $43 \%$ \\
\hline \multirow{2}{*}{ Acquisition of the area } & inheritance & 5 & $71 \%$ \\
& purchase & 2 & $29 \%$ \\
\hline
\end{tabular}

The average age of the respondents was 57 years. The size of the forest area per owner averaged about 25 hectares but varied widely from about five to 65 hectares. In addition, some of the respondents' property was divided into smaller parcels that were not contiguous and spatially separated. The size of the area damaged by fire also varied. The smallest damaged area was 1.1 hectares, the largest encompassed 14 hectares.

\subsection{Results addressing the research questions}

\section{(Q1) Do economic benefits play a significant role in the reforestation of burned areas?}

None of the seven respondents is economically dependent on forest management. The forest is mostly passed down through generations in the family and has a tremendous idealistic value for the owners. Three of the respondents have leased their land to the Bardenitz forest cooperative, which manages the respective areas. Of the four privately managed areas, three people cut firewood for their own use. The economic benefit plays a minor role for the respondents overall. Nevertheless, the desire for financial recognition for the work performed was expressed and the need not to make a financial loss between income and expenses.

\section{(Q2) Do forest owners want to change their forest management in the future?}

We have found that none of the interviewees would like to replant their entire area with a pine monoculture in the future. Reasons for this were doubts about the future viability of pine, aesthetic preferences, and the hope that a mixture of tree species would provide stability if one tree species fails (e. g., due to calamities or poor soil conditions). Accordingly, doubts were also expressed if Treuenbrietzen is suitable for the deciduous or mixed forest, mainly due to the sandy soil conditions. 
When asked which tree species have been planted or will be planted in the future on the burned area, it became clear that pine continues to lead the way. Also frequently mentioned were poplar, oak, and sporadically birch (see figure 1). It should be noted that the tree species composition resulted both from planting and wild growth (e.g., from wind dispersal). For example, according to the respondents, birch and poplar were never planted, while, oak was brought to the plots exclusively through plantings. At the same time, pine was planted and also propagated independently.

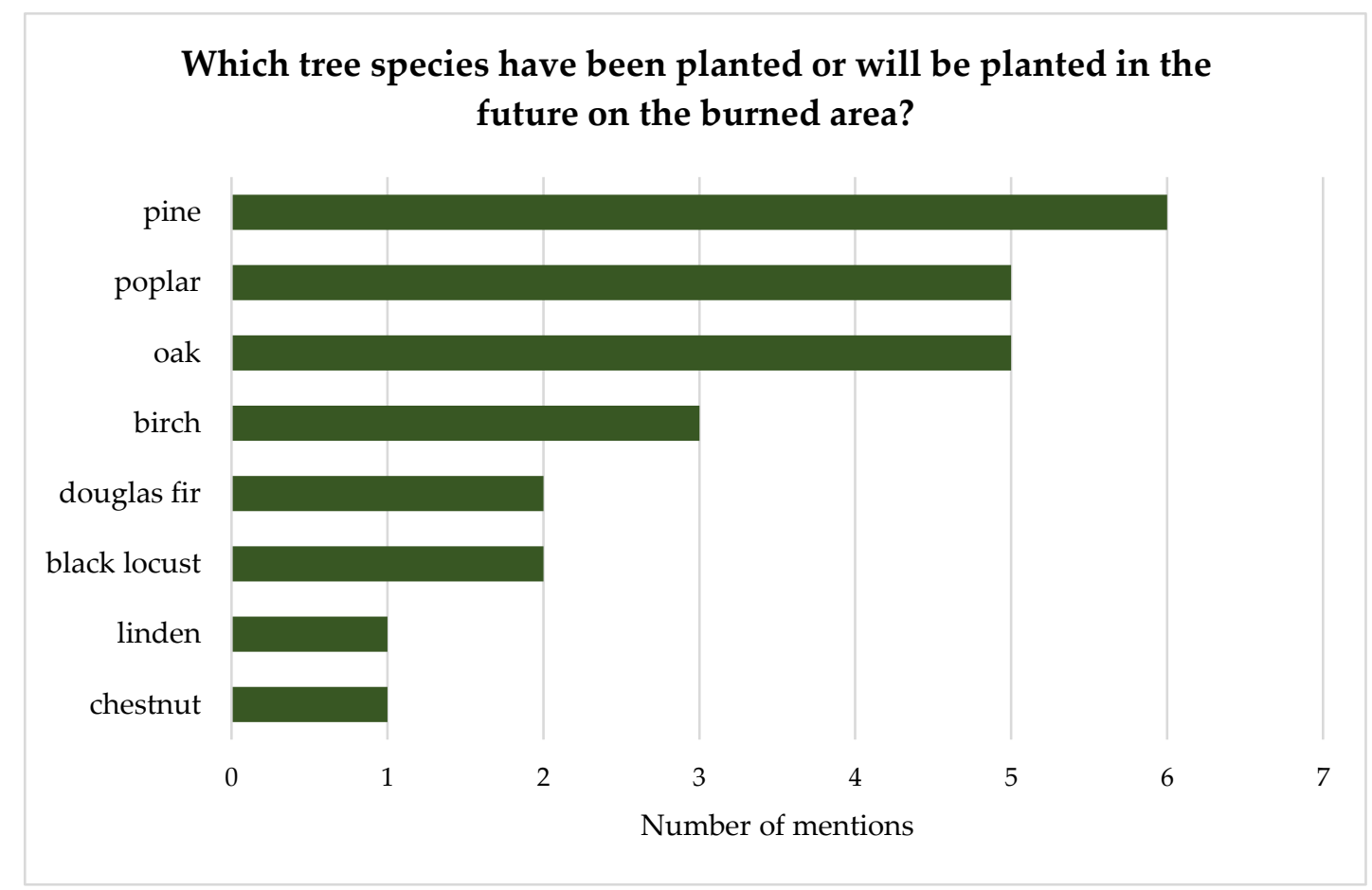

Figure 1: Respondents answers to the tree species for reforestation. 
Different motivations guided the decisions for reforestation. In addition to influence from research projects (mentioned three times), soil conditions (mentioned twice) also played a role. Through two persons, the hope was expressed that converting to a mixed forest would increase the resistance against a renewed fire. Also mentioned once each was the influence by neighbors, the desire for natural development, and the positive transformation of the landscape by deciduous trees.

The question about problems that could face forest management in the future was most frequently answered with increasing drought and lack of profit for future generations. Increasing frequency of fires were feared. Respondents feared a potential decline in profitability of the forest during the conversion of pine monospecific forests to mixed deciduous forests (see figure 2).

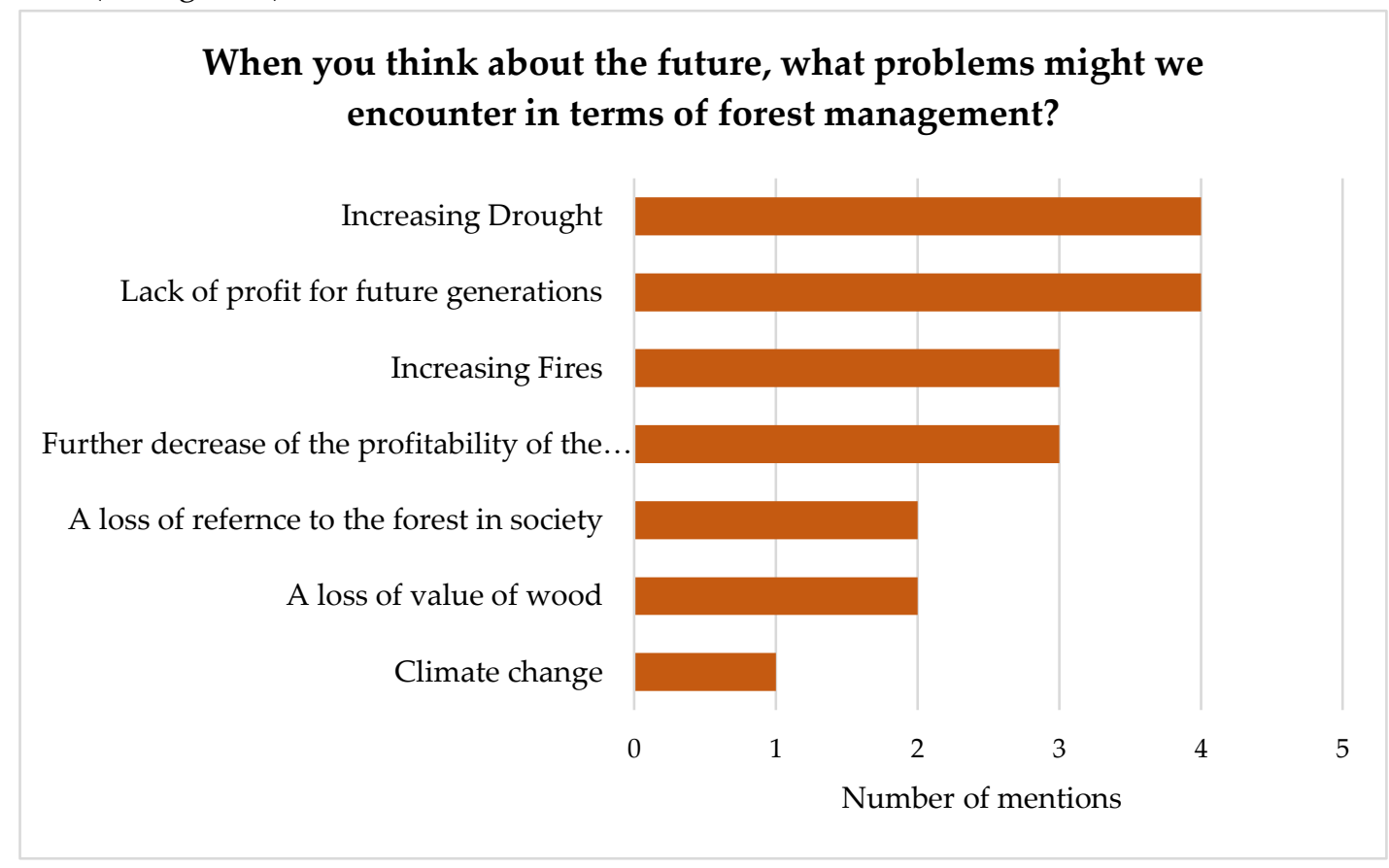

Figure 2. Respondents answers about possible future problems of forest management.

\section{Discussion}

Climate change is expected to increase drought in the future, which will simultaneously increase the likelihood of forest fires (Glade et al., 2017; BMEL, 2020). The pine monoculture, which is most common in Brandenburg, is no longer sustainable, and planting mixed stands can make forests more resilient to disturbances such as forest fires (Schelhaas et al. 2010).

Studies such as Waks et al. (2019) show that a large proportion of private forest owners nevertheless want to reforest their forest with the same species composition as before the fire and that nearly no thought is given to adaptations to climate change. The result from this study rejects this notion. All respondents had expressed their opposition to the pine monoculture that had previously prevailed. Yet, decisions did not always seem to be purposefully made according to climate adaptations but were influenced externally by research projects, risk mitigations, aesthetic reasons, or neighbors, among other factors.

As already mentioned, private forest owners are of great importance, owning $48 \%$ of the forest area in Germany. The fragmentation of the area is a particular challenge (BMEL 2012). In addition, the owners of small forests are often 
hardly familiar with the requirements of sustainable forest management due to spatial distances, urban lifestyle, or their professional activities. Furthermore, the financial returns from forest management are often negligible in the owner's total income (BMEL 2012). A similar picture emerged during the survey conducted in Treuenbrietzen. The forest areas are partly spatially distributed and vary significantly in size. At the same time, forest management goals differ from economic interests (e.g., by the forest cooperative) to experiments of research projects to private forest owners who want to leave the forest area to themselves. All these circumstances point to the challenge of finding a consensus between the forest owners.

Regarding the motives for forest management, the European study by Feliciano et al. (2017) has shown that the preservation of the forest for future generations has a higher priority than the economic idea. The present survey is consistent with these results. The forest has a tremendous idealistic value for private forest owners and is seen as a generational matter. Economic aspects play a subordinate role.

\section{Conclusions}

In support of other findings, one recommendation that emerges from this research is the need for an increased focus on forestry advice and support from the federal and state governments. In particular, information should be communicated on how climate change may affect local forests and what actions can be taken. There is already a lot of funding and support in this area, but this study's interviews showed that it is not received by all forest owners or accepted in this form. In this regard, ways need to be found to address this complex discrepancy and build a common consensus.

Author Contributions: S.S. conceptualized and co-wrote the paper. S.S. wrote the project proposal. R.F. did the interviews and data analysis. R.F. wrote the first draft of the paper. K.F. contributed to the conceptualization and co-wrote the paper.

Funding: This research was funded by The German Federal Ministry for Food and Agriculture (Bundesministerium für Ernährung und Landwirtschaft - BMEL) through the project "ErWiN: Expanding the ecological, silvicultural, and technical knowledge about forest fires. Sub-project 5: Development of silvicultural strategies for the regeneration of fire-damaged stands" (ErWiN: Erweiterung des ökologischen, waldbaulichen und technischen Wissens zu Waldbränden. Teilvorhaben 5: Entwicklung waldbaulicher Strategien für die Verjüngung feuergeschädigter Bestände), grant number 2219WK54E4. The APC was funded by the Karlsruhe Institute of Technology.

Institutional Review Board Statement: Not applicable

Informed Consent Statement: Not applicable

Data Availability Statement: The data used in this study can be accessed by contacting the corresponding author.

Acknowledgments: We want to thank foresters Mr. Uwe Honke and Ms. Karin Heintz for their support.

Conflicts of Interest: The authors declare no conflict of interest.

\section{References}

Allgaier Leuch, Barbara; Streit, Kathrin; Brang, Peter (2017). Naturnaher Waldbau im Klimawandel. Merkblatt für die Praxis 59.1. WSL Birmensdorf

Bathke, Manfred; Orlowski, Carmen (2020) Bewertungs- und Fallstudienbericht-M02 „Beratungs-, Betriebsführungsund Vertretungsdienste (Artikel 15)“ sowie M08 „Investitionen in die Entwicklung von Waldgebieten und Verbesserung der Lebensfahigkeit von Waldern (Waldumbau und Waldbrandschutz)“. Laufende Bewertung des Entwicklungsplans für den Ländlichen Raum (EPLR) Brandenburgs und Berlins 2014-2020. 
Brang, Peter; Spathelf, Peter; Larsen, J. Bo; Bauhus, Jürgen; Boncčìna, Andrej; Chauvin, Christophe, ... \& Svoboda, Miroslav (2014). Suitability of close-to-nature silviculture for adapting temperate

Bundesanstalt für Landwirtschaft und Ernährung (BLE) (2020). Waldbrandstatistik der Bundesrepublik Deutschland für das Jahr 2019. Korrigierte Fassung vom 25.06.2020. Bonn

Bundesministerium für Ernährung und Landwirtschaft (BMEL) (2012): Wald - überwiegend in privater Hand. Bonn: Bundesministerium für Ernährung und Landwirtschaft (BMEL). Available online at: https://www.bundeswaldinventur.de/dritte-bundeswaldinventur-2012/waldland-deutschland-waldflaeche-konstant/wald-ueberwiegend-in-privater-hand/ (Last accessed: 20.02.2021)

Bundesministerium für Ernährung und Landwirtschaft (BMEL) (2020): Am Puls des Waldes. Umweltwandel und seine Folgen - ausgewählte Ergebnisse des intensiven forstlichen Umweltmonitorings. Bonn. ). Available online at: https://www.bmel.de/SharedDocs/Downloads/DE/Broschueren/puls-des-waldes.html (Last accessed: 02.05.2021)

City of Treuenbrietzen (n.y.). Available online at: https://www.treuenbrietzen.de/front_content.php?idart=1184 (Last accessed on: 24.11 .2020$)$

European forests to climate change. Forestry: An International Journal of Forest Research, 87(4), 492-503.

Feliciano, Diana; Bouriaud, Laura; Brahic, Elodie; Deuffic, Philippe; Dobsinska, Zuzana; Jarsky, Vilem, ... \& Ficko, Andrej (2017). Understanding private forest owners' conceptualisation of forest management: Evidence from a survey in seven European countries. Journal of Rural Studies, 54, 162-176.

Glade, T.; Hoffmann, P.; Thonicke, K. (2017): Dürre, Waldbrände, gravitative Massenbewegungen und andere klimarelevante Naturgefahren. In: Brasseur, G.; Jacob, D.; Schuck-Zöller, S. (Hrsg.): Klimawandel in Deutschland. Springer Verlag. DOI 10.1007/978-3-662-50397-3_12

Granados, María E.; Vilagrosa, Alberto; Chirino, Esteban \& Vallejo, V R. (2016). Reforestation with resprouter species to increase diversity and resilience in Mediterranean pine forests. Forest Ecology and Management, 362, 231-240.

Holsten, Anne; Dominic, Anto R.; Costa, Luís \& Kropp, Jürgen P. (2013). Evaluation of the performance of meteorological forest fire indices for German federal states. Forest Ecology and Management, 287, 123-131.

Kuckartz, U. (2018): Qualitative Inhaltsanalyse. Methoden, Praxis, Computerunterstützung. 4., überarbeitete Auflage. Weinheim: Beltz Verlagsgruppe

Ministerium für Landwirtschaft, Umwelt und Klimaschutz des Landes Brandenburg (MLUK) (2019) Waldzustandsbericht 2019 des Landes Brandenburg. Eberswalde. Available online at: http://www.forstliche-umweltkontrollebb.de/info/wze2019_bb.pdf (Last accessed: 02.05.2021)

Ministerium für Ländliche Entwicklung, Umwelt und Landwirtschaft des Landes Brandenburg (MLUK) (2018a): Waldzustandsbericht 2018 des Landes Brandenburg. Eberswalde

Ministerium für Ländliche Entwicklung, Umwelt und Landwirtschaft des Landes Brandenburg (MLUK) (2018b):

Waldbrandstatistik 2018. Eberswalde 
Ministerium für Ländliche Entwicklung, Umwelt und Landwirtschaft des Landes Brandenburg (MLUL) (2015) Wälder Brandenburgs. Ergebnisse der ersten landesweiten Waldinventur. Referat 34 - Wald und Forstwirtschaft. Potsdam. Available online at: https://www.sdw-brandenburg.de/cms/upload/Waldwissen/WaldwissenWald_Brandenburg_Broschuere_Ergebnisse_Waldinventur.pdf (Last accessed: 02.05.2021)

Niebert K., Gropengießer H. (2014) Leitfadengestützte Interviews. In: Krüger D., Parchmann I., Schecker H. (eds) Methoden in der naturwissenschaftsdidaktischen Forschung. Springer Spektrum, Berlin, Heidelberg. https://doi.org/10.1007/978-3-642-37827-0_10

Reinders, H. (2016). Qualitative Interviews mit Jugendlichen führen. Ein Leitfaden. 3. Auflage. München: Oldenbourg Wissenschaftsverlag.

Schelhaas, Mart-Jan; Hengeveld, Geerten; Moriondo, Marco; Reinds, Gert J.; Kundzewicz, Zbigniew W.; Ter Maat, Herbert \& Bindi, Marco (2010). Assessing risk and adaptation options to fires and windstorms in European forestry. Mitigation and Adaptation Strategies for Global Change, 15(7), 681-701.

Umweltbundesamt (UBA) (26.08.2020): Waldbrände. Available online at: https://www.umweltbundesamt.de/daten/landforstwirtschaft/waldbraende\#waldbrande-in-deutschland (Last accessed: 25.11.2020)

Waks, Lulu; Kocher, Susan D.; Huntsinger, Lynn (2019): Landowner Perspectives on Reforestation following a HighSeverity Wildfire in California. In: Journal of Forestry 117 (1), 30-37. DOI: 10.1093/jofore/fvy071 